\title{
CHALLENGES FOR THE UNFCCC IN INDONESIA'S DECENTRALISATION*
}

\author{
Melvin Salahuddin ${ }^{* *}$
}

\begin{abstract}
This article is an examination of the implementation of the United Nations Framework Convention on Climate Change (UNFCCC) as a Multilateral Environmental Agreement (MEA) in Indonesia. It identifies domestic challenges of the Convention in Indonesia's decentralisation. The implementation of decentralisation policy in 2001 worsens the inherent problems faced by the Convention in Indonesia's legal system. As a MEA, the Convention contains only general rules for the state parties and no specific legal obligation to reduce emission. The Convention also has legitimacy problems. The Indonesia's method to transform treaties into domestic legal system is still problematic. These two challenges are worsened by the implementation of decentralisation policy. The national government faces difficulties to drive lower government units to adhere to the Convention rules because they have new authorities that can constraint effort to achieve the goal of the Convention.
\end{abstract}

Keywords: UNFCCC, Decentralization, Treaty Implementation

\begin{abstract}
Abstrak
Artikel ini adalah eksaminasi terhadap implementasi Konvensi Perubahan Iklim (UNFCCC) yang merupakan satu bentuk perjanjian multilateral di bidang lingkungan (MEA). Artikel ini mengidentifikasi tantangan yang dihadapi oleh UNFCCC dalam konteks desentralisasi di Indonesia. Kebijakan desentralisasi telah memperburuk masalah yang selama ini telah dihadapi oleh UNFCCC di Indonesia. Sebagai salah satu MEA, UNFCCC hanya mengandung aturan umum untuk negara-negara anggota dan tidak mempunyai kewajiban hukum khusus untuk mengurangi emisi. Tanpa kewajiban khusus, negara-negara anggota, terutama negara berkembang, belum terikat atas target level emisi tertentu. Selain itu, UNFCCC mempunyai masalah legitimasi di Indonesia yang berhubungan dengan metode transformasi perjanjian internasional ke dalam hukum nasional. Masalah legitimasi membuat UNFCCC menjadi sulit untuk mengikat entitas di dalam negeri. Dalam konteks desentralisasi, kedua masalah tersebut memberikan kesulitan bagi pemerintah pusat dalam mengarahkan pemerintah daerah untuk melaksanakan upaya untuk mencapai tujuan UNFCCC. Desentralisasi memberikan kewenangan pemerintah daerah untuk membuat kebijakan yang dapat bertentangan dengan UNFCCC.
\end{abstract}

Kata Kunci: UNFCCC, Desentralisasi, Implementasi Perjanjian Internasional

* This article is an excerpt of a chapter in a dissertation submitted for a PhD degree at Otago University of New Zealand. I thank Ms. Ceri Warnock, Ms. Nicola Wheen and Prof. Simon Butt for their valuable insights and comments during the amendments process of the Chapter.

** Staff at Law and Human Rights Bureau of South Sulawesi Provincial Government. Obtained Bachelor of Economics (S.E.) from Hasanuddin University (1997), Master of Public and International Law (M. Pub\&Int Law) from Melbourne University (2006), and Doctor of Philosophy (Ph.D) from Otago University (2014). E-mail: melvsal@gmail.com. 


\section{Introduction}

"First, your return to shore was not part of our negotiations nor our agreement so I must do nothing. And secondly, you must be a pirate for the pirate's code to apply and you're not. And thirdly, the code is more what you'd call "guidelines" than actual rules." (Captain Barbossa, Pirates of the Caribbean: the Curse of the Black Pearl).

The words of Barbossa above cynically but accurately describe the position of the United Nations Framework Convention on Climate Change (UNFCCC/Convention) in the context of Indonesia's decentralisation. Though Indonesia is a party of the Convention, the Multilateral Environmental Agreement (MEA) cannot automatically bind the lower government units, the provincial and local governments, as they are not involved in the climate negotiations (although they have the burden to implement the Convention). The Convention also lacks in legitimacy. The process of transforming treaties into Indonesia's legal system has raised legality issues and consequently, it is not clear whether the Convention has properly become a part of Indonesian law. In addition, Indonesia has no firm legal obligation to reduce Greenhouse Gas Emissions (GHG) under the Convention. Without a firm legal obligation, what substantive obligations will Indonesia perform? These issues have characterised the existence of the Convention in Indonesia's decentralisation.

This article aims to examine the Convention in Indonesia's decentralised state model. How has decentralisation constrained the national government in fulfilling its commitment to the Convention? It is argued that a combination of legal and political constraints arising in decentralised Indonesia have burdened the national government in performing climate efforts under the Convention.

\section{The Convention in Indonesia's Legal System}

The Convention, as an MEA, emphasises the vital role of the national government. The national government represents a nation-state in negotiating an MEA at the international level. ${ }^{1}$ In return, the national government must ensure compliance of the MEA, provided that the MEA is applicable to all the territories of the state parties. ${ }^{2}$ To ensure its national application, however, domestic factors are vital in determining its success. In this case, the implementation of the MEA's rules is a vital process, and will depend on each state's domestic law. ${ }^{3}$

\footnotetext{
${ }^{1}$ See UNEP Manual on Compliance with and Enforcement of Multilateral Environmental Agreements (UNEP, 2006) at 51.

2 Anthony Aust, Modern Treaty Law and Practice, (2nd ed, Cambridge, UK, 2007), p. 200.

3 Daniel Bodansky, The Art and Craft of International Environmental Law, (Harvard University Press, Cambridge (Mass) 2010), p. 212.
} 


\section{A. Review of the Convention in Indonesia's Legal System}

\section{Treaties in Indonesia's Law}

The legal status of the Convention in Indonesia's legal system is unclear; as the legitimacy of an international agreement as a source of Indonesia's law is problematic. The status of the ratifying laws (acts and presidential regulations) is subject to questions as to whether those laws have substantive character or is only procedural, especially when they have no further implementing regulations. ${ }^{4}$

In general practice, an international agreement agreed by the national government is ratified by an act or a presidential decree (this decree is in the form of a presidential regulation since the introduction of Act No. 10 2004). ${ }^{5}$ Article 9 of Act No. 24/2000 concerning on Treaties states that "Ratification of a treaty as referred to in paragraph (1) shall be conducted by way of a law or a presidential decree." 6

This article suggests that Indonesia follows a dualist approach, whereby treaties cannot have effect on national jurisdiction unless they have been specifically transformed into national law by legislations or any other means of legislative procedures. ${ }^{7}$ In order to be enforced by judges in a domestic court, international law must be made as parts of the national law. ${ }^{8}$ This approach is in contrast with a monist approach, which perceives that "treaties may, without legislation, become part of domestic law once they have been concluded in accordance with the constitution and they have entered into force for the state". ${ }^{9}$

Furthermore, an act or a presidential regulation that is enacted following the conclusion of an international agreement only contains two articles. The first is Indonesia's recognition of the relevant international agreement along with its provisions, and the second is recognition that such an agreement comes into effect in Indonesia's legal system. ${ }^{10}$ This practice suggests two implications. First, a treaty becomes a part of Indonesia's law after the enactment of a ratifying act or presidential regulation. An act or a presidential regulation is a recognised source of law in Indonesia's legal system. ${ }^{11}$ Second,

4 Direktorat Jenderal Hukum dan Perjanjian Internasional, Departemen Luar Negeri Perjanjian Internasional Dalam Teori dan Praktek di Indonesia: Komplilasi Permasalahan (International Agreement in Theory and Practice in Indonesia), (Indonesian Ministry of Foreign Affairs, Jakarta, 2008), p. 6.

${ }^{5}$ See the Forming of Laws Act 200410 (revoked), art 46, 54 and 56.

6 The English translation of Act 24/2000 on International Agreement <http://www.indonesiaottawa.org/indonesia/law treaties.php.html> at 18 June 2010.

7 Malcolm N. Shaw, International Law, (5th Ed, Cambridge University Press, New York, 2003), p. 129.

${ }^{8}$ Gillian D. Triggs, International Law: Contemporary Principles and Practices, (Butterworths Law, London, 2006), p. 105

9 Anthony Aust, Handbook of International Law, (Cambridge University Press, New York, 2005), p. 80 .

10 See for instance, the Validation of Covenant on Economic, Social, and Cultural Rights Act 2005 11 (Indonesia). In the level of a presidential regulation, see for instance, President Regulation 20102 (Indonesia) on the Validation of Association of South East Asian Nation (ASEAN) Trade in Goods Agreement.

11 Indonesia's law sources and hierarchies are as follows: (1) Constitution; (2) TAP MPR; (3) Act (legislation)/Government Regulation as the substitute of an Act in the event of Emergency (PERPU); (4) Government Regulation; (5) President Regulation; (6) Provincial Regulation; (7) Local Government/City Regulation. See the Forming of Law Act 201112 (Indonesia), art 7 (1). Other sources of law can be issued by 
the text of a treaty will become directly applicable in the legal system once a ratifying law is introduced, and will be applicable according to a specified date.

However, although the transformation process employs a recognised source of law in Indonesia's legal system, the ratifying law is still subject to legality issues. It is not yet clear if such practice actually transforms international rules into Indonesia's legal system or only recognises that Indonesia has committed to an international agreement.

In fact, the legal status of the ratifying laws has raised concerns in Indonesia. Agusman suggests that two sides to the debates on the status of ratifying law have emerged. The first group believes that ratification in the form of an act or a Presidential Regulation, has transformed international norms into national law. The laws therefore have substantive character because they have normative effect. ${ }^{12}$ The second group perceives that ratification laws are procedural measures only: these laws are only approval from DPR and thus they have no normative effects. ${ }^{13}$ This division on the meaning of ratification can create problems in understanding the legality of ratifying laws.

In between these stances, Manan suggests that if the ratification of a treaty resulted in the form of an act, this act, as long as no specific provisions stated otherwise, would have the same status as other acts. ${ }^{14}$ Manan, however, raises concerns that this perception contains a contradiction when it is perceived from the legal source and law making concepts. On one hand, a treaty contains norms that are debated in international levels (not in the Parliament), while on the other hand the ratified-treaty takes form as an act, which is a valid legal source, is debated in and agreed by the Parliament. ${ }^{15}$

Kusumaatmadja has a different perspective. He claims that although the Indonesian Constitution does not provide an indication whether Indonesia follows dualism or monism, Indonesia tends to follow monism. ${ }^{16}$ To implement international law in the national legal system, Indonesia tends to accept and enforce all international obligations automatically after a treaty is ratified, without the need to enact an implementing legislation. ${ }^{17}$ In addition, the amendment of a treaty will directly bind Indonesia. ${ }^{18}$ Unfortunately,

government bodies, such as ministries, as long as there is an order from a higher law source or pursuant to their authorities. See art 8 (2). TAP MPR is a decision of the People Assembly. TAP MPR which were enacted from 1960-2002 and never been revoked are still in force. See the elucidation of art 7 (1) b.

12 Damos Dumoli Agusman, "Status Hukum Perjanjian Internasional Dalam Hukum Nasional Republik Indonesia: Tinjauan dari Perpsektif Praktek Indonesia” ("Legal Status of International Agreement in National Law of Rebublic of Indonesia: Study of Indonesian Practical Perspective"), (2008) Paper presented in the Focus Group Discussion on the Status of Treaty in Indonesian Legal System, organized by Department of Foreign Affair and Padjajaran University, Bandung November 29th 2008, p. 4.

13 Ibid.

14 Bagir Manan, "Akibat Hukum di Dalam Negeri Pengesahan Perjanjian Internasional: Tinjauan Hukum Tata Negara" Paper presented in the Focus Group Discussion on the Status of Treaty in Indonesian Legal System, organized by Department of Foreign Affair and Padjajaran University, (Bandung November 29th 2008), p. 10.

15 Ibid., p. 9-10.

${ }^{16}$ Muchtar Kusumaatmadja, Pengantar Hukum Internasional (Introduction of International Law), (vol 1, Ed 9, 1990), p. 65-67.

17 Ibid.

18 Ibid. 
Kusumaatmadja adds, this tendency is not a deliberate procedure adopted by the parliament and the Indonesian government but rather is a practice that has developed over time. ${ }^{19}$

The Kusumaatmadja's approach of observing practice is one possible way to clarify the legality of treaties. However, observing practices might also create confusion: whether a ratifying act is enough for a treaty to be implemented, or a ratifying act still needs implementing acts. This confusion is manifest in practice. The Indonesian Foreign Affairs Ministry has identified inconsistencies in implementing international agreements. In some cases, even though a treaty has already been ratified by an act or regulation, it still requires another act or regulation to be implemented into the national legal system..$^{20}$

This legality concern, however, seems irrelevant before the courts. According to Hadyono, the use of international law by courts depends mainly on the status of a treaty under national law, and specifically whether a treaty has been transformed into Indonesia's law. ${ }^{21}$ At the same time, however, judges are not absolutely bound to consider the legitimacy of the ratifying laws when they want to apply those laws in a case. ${ }^{22}$ In exercising their judicial power, judges also consider the political position of the national government on issues relating to an international agreement. ${ }^{23}$ Thus, one could say that a valid legal status is vital for international laws to apply in Indonesia's legal system, but at the same time the legality issue is irrelevant, as the courts will follow the political stance of the national government. Even though a treaty has a legality issue, if the national government is willing to apply its rules, the court will follow.

In a recent case, the Constitutional Court examined Act No. 38/2008 on the Ratification of the Association of South East Asian Nations (ASEAN) Charter ${ }^{24}$ A coalition of NGOs perceives that the implementation of ASEAN Charter through the Act creates a single ASEAN market, which may hamper national industry, especially on small and medium scale industry. Therefore, the coalition perceives that the Charter is against the Constitution, ${ }^{25}$ and urges ${ }^{26}$ the Court to revoke article $1(5)^{27}$ that requires Indonesia to implement a

${ }^{19}$ Ibid.

21 Suparti Hadyono, "Praktek Penerapan Perjanjian Internasional Dalam Putusan Hakim” ("Practice of International Agreement's Application in Judges' Verdict") (2008) Paper Presented in the Focus Group Discussion on the Status of Treaty in Indonesian Legal System, organized by the Ministry of Foreign Affairs and Padjajaran University, (Bandung November 29th, 2008), p. 2.

22 Ibid.

23 Ibid.

24 ASEAN Charter (adopted in Singapore, November 20, 2007, enter into force December 2008).

25 See the Decision of Constitutional Court No. 33/PUU-IX/2011 on the Examination of Act No. 38/2008 on the Ratification of Charter of the Association of Southeast Asian Nations, p. 94.

26 See the Decision of Constitutional Court No. 33/PUU-IX/2011 on the Examination of Act No. 38/2008 on the Ratification of Charter of the Association of Southeast Asian Nations, p. 94.

27 See ASEAN Charter (adopted in Singapore, November 20, 2007, enter into force December 2008), art 1 (5): "to create a single market and production base which is stable, prosperous, highly competitive and economically integrated with effective facilitation for trade and investment in which there is free flow of goods, services and investment; facilitated movement of business persons, professionals, talents and labour; and freer flow of capital." 
single ASEAN market, and article 2 (2) (n) ${ }^{28}$ that reduces Indonesia's economic sovereignty in creating its national economic policies. After almost 2 years of examination, the Court concluded its decision on February 4th 2013. In its decision, the Court, by majority, rejects the petition to revoke the articles. ${ }^{29}$

This case can show how the status of a ratifying act can create a dilemma for Indonesia. On one hand, the fact that Act No. 38/2008 is a ratifying act does not make it different from non-ratifying acts. Thus, the Constitutional Court has the authority to examine the Act, ${ }^{30}$ including the Charter itself as it is accepted as a part of the Act. ${ }^{31}$ On the other hand, norms in the Charter are a result of negotiations between the members of ASEAN in international level. This makes the norms in the Charter different from norms in non-ratifying acts which are debated by the executive and the Parliament. As a result, the Constitutional Court faces difficulties in revoking any articles in the Charter even though they contradict Indonesia's Constitution.

In its decision, the Court concludes that the arguments provided by the Coalition of NGOs do not have a sound legal basis, because of the Charter which allows members of ASEAN to later decide whether or not to implement the Charter, which can be done so through necessary measures, including the enactment of a new act. ${ }^{32}$ Art 5 (2) states: "member shall take all necessary measures, including the enactment of appropriate domestic legislation, to effectively implement the provisions of this Charter and to comply with all obligations of membership." 33 In this case, the word "shall" indicates that the Charter strongly encourages ASEAN members to introduce necessary measures for the implementation of the Charter. However, Indonesia has not yet implemented Article 5 (2) of the ASEAN Charter as there are no domestic measures introduced yet for the implementation of the Charter. Therefore the Court concludes that article 5 (2) is not effectively in force in Indonesia's jurisdiction. ${ }^{34}$ The decision seems to suggest that since no domestic legislation has been introduced (except the Ratifying Law of the ASEAN Charter), the Charter is not effective yet in Indonesian law, and the Court only examines Act No. 38/2008 as an instrument of transformation but not domestic measures for the implementation of the Charter.

28 See ASEAN Charter (adopted in Singapore, November 20, 2007, enter into force December 2008), art 2 (2) (n): "adherence to multilateral trade rules and ASEAN's rules-based regimes for effective implementation of economic commitments and progressive reduction towards elimination of all barriers to regional economic integration, in a market-driven economy."

29 See the Decision of Constitutional Court No. 33/PUU-IX/2011 on the Examination of Act No. $38 / 2008$ on the Ratification of Charter of the Association of Southeast Asian Nations, part 5.

30 See the Decision of Constitutional Court No. 33/PUU-IX/2011 on the Examination of Act No. 38/2008 on the Ratification of Charter of the Association of Southeast Asian Nations, p. 181.

31 See Ratification of the Association of South East Asian Nations (ASEAN) Charter Act 2008 38, art 1.

32 See the Decision of Constitutional Court No. 33/PUU-IX/2011 on the Examination of Act No. 38/2008 on the Ratification of Charter of the Association of Southeast Asian Nations, part 4, para 4.3.

33 See ASEAN Charter (adopted in Singapore, November 20, 2007, enter into force December 2008), art 5 (2): "member shall take all necessary measures, including the enactment of appropriate domestic legislation, to effectively implement the provisions of this Charter and to comply with all obligations of membership".

34 See the Decision of Constitutional Court No. 33/PUU-IX/2011 on the Examination of Act No. 38/2008 on the Ratification of Charter of the Association of Southeast Asian Nations, part 3, para 3.24. 
The decision cannot provide a complete clarification on the status of a treaty in Indonesia's law. The Court's decision only recognises that the legality of Act No. 38/2008 that ratifies the ASEAN Charter equates with other acts that are debated in and agreed to by the Parliament. This makes it a subject within the authority of the Constitutional Court. Thus, this case shows that a ratifying law (in this case Act No. 38/2008) is a valid instrument that makes the ASEAN Charter part of Indonesia's law. The recognition of the function of the ratification Act (Act No 38/2008) by the Court is very vital to clarify the status of ratification laws. The Court's decision can reduce uncertainty on the legality of ratification laws in Indonesia.

Unfortunately the Court's decision leaves a question. If Act No. 38/2008 has transformed the ASEAN Charter into a valid legal source, then can the Court revoke any articles in the text of the Charter? Thus, will the Court revoke the article 1 (5) and article 2 (2) (n) when they are in contradiction with Indonesia's Constitution? This question is particularly important as the Court rejected the application from the NGOs to revoke the articles because Indonesia has not yet introduced the "necessary measures" that are required by article 5 (2) of the Charter, not because the articles are in line with Indonesia's Constitution. It seems to suggest that when "necessary measures" have been implemented, they have potential to contradict Indonesia's Constitution and therefore the articles can be revoked by the Court. Should this be the Case, Indonesia will ask for a re-negotiation, or propose a reservation. This makes the future implementation of ASEAN Charter uncertain when other ASEAN countries face a similar situation.

The existence of the "necessary measures" requirement for the Charter to have domestic implementation might suggest that Charter itself provides room for Indonesia to use Act 38/2008 as a mean for ratification but not implementation measures. Thus, although the state parties have ratified the Charter, itstill needs implementing measures to have domestic effects. However, it is important to note that the Charter is a multilateral treaty and functions as legal and institutional framework for ASEAN. ${ }^{35}$ As a result, this Charter functions as a guidance of the ASEAN countries to achieve future consensus. It is this future consensus that might require domestic implementation measures. Yet, the potential contradictions within the Constitution of each ASEAN nations still exist, which can harden the future negotiations between the ASEAN nations on the implementation of the Charter through domestic measures.

Moreover, the Court's decision implies that the use of an act to ratify a treaty is not a plausible method. The Court states that the use of an act to ratify a treaty should be re-considered. ${ }^{36}$ This suggestion indicates that the Constitutional Court realises that examining a ratifying act, can be problematic. When the Court revokes an article from a treaty due to contradictions towards the Constitution, Indonesia might face consequences from other contracting parties. In international law, a state is under general obligation to comply with

35 See the preamble of ASEAN Charter (adopted in Singapore, November 20, 2007, enter into force December 2008): "to establish through this Charter, the legal and institutional framework for ASEAN."

36 See the Decision of Constitutional Court No. 33/PUU-IX/2011 on the Examination of Act No. 38/2008 on the Ratification of Charter of the Association of Southeast Asian Nations, part 3, para 3.23, point 3, p. 196. 
the treaty, and in principle will bear responsibility for breaches, conducted by its judicial, legislative and executive organs. ${ }^{37}$ The use of an act to ratify a treaty can drive the Court to examine it, while a revocation can breach Indonesia's international commitments. Thus, the Court's decision implies that Indonesia should change the method to transform a treaty into national law.

\section{The Convention in Indonesia}

The general practice of ratification in Indonesia creates problems for many MEAs. Because many MEAs only contain general rules, ${ }^{38}$ even when a ratifying law is accepted as a domestic implementation measure, MEAs can only become a soft legal instrument in Indonesia.

The Convention is not an exception. Act No 6/1994, the Ratifying Act of the Convention, only contains two articles: a validation article and an article specifying the date that the Convention comes into effect in Indonesia's legal system. ${ }^{39}$ This suggests that the character of the Convention as a soft legal instrument is directly transformed into Indonesia's legal system. The Convention recognises that "states should enact effective environmental legislation...." ${ }^{40}$ In addition, state parties should "protect the climate system for the benefit of present and future generations of humankind, on the basis of equity and in accordance with their common but differentiated responsibilities and respective capabilities." ${ }^{\prime 1}$ The term "should" indicates that the Convention only encourages its state parties to introduce domestic law as an implementation measure, which is vital for achievement of the ultimate goal of the Convention. ${ }^{42}$ Thus, Act. No. 6/1994 directly inherits the "encouragement" character of the Convention, without any changes that can improve the character of the Convention in the legal system.

Furthermore, the enactment of Act No. 6/1994 does not guarantee that the Act will become a binding consideration on the enactment of other acts that are associated with climate change problems. For instance, prior to decentralisation in 1999, the main environmental protection was Act No. 23 of 1997 (replaced by Act No. 32/2009) concerning environmental management (the Environmental Management Act, EMA). The EMA emphasised the need to consider climate change as an element in environmental management, along with spatial planning, biodiversity protection, and the use of natural

${ }^{37}$ Malcolm N. Shaw, see note 9, p. 128.

${ }^{38}$ See Patricia Birnie, Alan Boyle, and Catherine Redgwell, International Law and the Environment, (Oxford University Press, New York, 2009) at 13; Jutta Brunnée, "COPing with Consent: Law-Making under Multilateral Environmental Agreements" (2002) 15 (1) Leiden Journal of International Law (LJIL) 1 at 7; Alexandre Kiss and Dinah Shelton, Guide to International Environmental Law, (Martinus Nijhooff Publishers, the Netherlands, 2007), p. 78.

${ }^{39}$ See Validation on the United Nations Framework Convention on Climate Change (UNFCCC) Act 20046 (Indonesia).

${ }^{40}$ UNFCCC (opened for signature June 20, 1992, entered into force 21 March 1994) at introduction: "Recognizing that States should enact effective environmental legislation, that environmental standards, management objectives and priorities should reflect the environmental and developmental context to which they apply, and that standards applied by some countries may be inappropriate and of unwarranted economic and social cost to other countries, in particular developing countries". Emphasis added.

${ }^{41}$ UNFCCC (opened for signature June 20, 1992, entered into force 21 March 1994) art 3 (1).

42 UNFCCC (opened for signature June 20, 1992, entered into force 21 March 1994) art 2. 
resources. ${ }^{43}$ Yet, the EMA did not provide further measures to address climate change, and excluded Act. No. 6/1994 as a binding consideration. Similarly, the Forestry Act No. 41/1999 does not refer to the Ratifying Act of the Convention.

Indonesia's ratification of the Kyoto Protocol does not improve the character of the Convention either. Act No. 17/2004 concerning the validation of the Kyoto Protocol, in which the Ratifying Act of the Convention is one of its binding considerations, ${ }^{44}$ merely accepts the Protocol's rules. The use of the Ratifying Act as a binding consideration cannot change the soft character of the Convention, as Indonesia has no legal commitment to reduce GHG emissions under the Kyoto Protocol.

Another problem for the Convention is the status of its future decisions. As a MEA, the parties to the Convention will continue negotiating further agreement to improve the rules of the Convention. When the parties have achieved consensus under the Convention, what will be their status in Indonesia's legal system? This is particularly important as the case of the consensus can take form of a protocol (i.e Kyoto Protocol), decisions of Conference of the Parties (COP) or other forms agreed by the parties.

Accordingly, climate efforts that centre on the Convention and its Kyoto Protocol have faced legality issues in Indonesia. In addition, the Ratifying Acts of the Convention and the Protocol merely adopt their rules, which contain no specific obligations for Indonesia to reduce GHG emission.

\section{B. National Government Policy Initiatives and the Coordination Problem}

Facing legality issues and challenges relating to its soft character, political commitments are central for the Convention. In democracies, political commitments are exogenous factors that promote compliance. ${ }^{45}$ To this end, the national government has introduced several policy initiatives. The Ministry of Environment, for instance, has initiated and introduced the National Action Plan (NAP) on Climate Change, which guides government organs at national and lower levels in initiating climate mitigation and adaptation efforts. ${ }^{46}$ The NAP emphasises the importance of addressing climate change by improving coordination between various sectors and departments. ${ }^{47}$ In its mitigation plan, the NAP focuses on three sectors: energy, Land Use, Land Use Change and Forestry (LULUCF); and marine and fisheries. ${ }^{48}$ Adaptation efforts include actions to maximise water resources, agriculture, marine and fisheries, infrastructure, public health, forestry and biodiversity, and research and

${ }^{43}$ Environmental Management Act 199723 (Indonesia), art 9 (4).

${ }^{44}$ See Validation of the Kyoto Protocol Act 200417 (Indonesia).

45 Robert O. Keohane and Kal Raustiala, "Toward A Post-Kyoto Climate Change Architecture: A Political Analysis" (2008) 08-14 UCLA School of Law Law \& Economics Research Paper Series Research Paper, p. 2. See also Ailsa Ceri Warnock, "The Climate Change Regime: Efficacy, Compliance and Enforcement" (2004) 8 New Zealand Journal of Environmental Law, 99, p. 102.

46 Indonesia's Ministry of Environment, Rencana Aksi Nasional Dalam Menghadapi Perubahan Iklim (National Action Plan for Facing Climate Change), (Ministry of Environment, Jakarta, 2007), p. 2.

47 Ibid.

${ }^{48}$ Ibid., p. 33-52. 
development. ${ }^{49}$ The NAP also restates Indonesia's commitment to contribute to climate change efforts under the Convention and its Kyoto Protocol. ${ }^{50}$

Although the national government has introduced the NAP, coordination among different government organs can be challenging. One particular reason for this is that the causes of climate change involve many sectors that are under the authority of different departments. The NAP identifies two general problems Indonesia faces in relation to climate change issues. The first relates to the management of natural resources regarding land use, water resources, housing, LULUCF, and marine resources. The second focuses on energy consumption. ${ }^{51}$ Each of these sectors is under the authority of different ministries. However, no ministry is specifically responsible for coordinating climate change efforts. Although the Ministry of Environment designed the NAP, the Ministry has no authority over other ministries. In addition, the Ministry of Environment established the National Commission on Clean Development Mechanism (CDM).$^{52}$ Yet, this institution mainly functions as a Designated National Authority (DNA) of the CDM, which authorises CDM projects in Indonesia.

The President also established the National Board on Climate Change..$^{53}$ This Board is expected to improve coordination of climate change-related efforts domestically and to strengthen Indonesia's position in international climate change negotiations. ${ }^{54}$ This board has wide authority, from formulating policies, strategies and programs on climate change efforts and carbon trading, to coordinating, evaluating and implementing climate policies and programs. $^{55}$

However, this Board faces practical difficulties in coordinating the Ministries because of its institutional character. According to Asshiddiqie, Indonesia's constitutional law differentiates the hierarchy of the state and government organs according to their legal formation. ${ }^{56}$ Organs that are formed based on the Constitution's order have a higher hierarchy than those formed by an Act or lower laws. ${ }^{57}$ As the Presidential Regulation forms the Board, it has a lower status than the Ministries, which are formed by order of the Constitution. ${ }^{58}$ As a result, it can be difficult for the Board to undertake its coordination function in relation to Ministerial policies and regulations.

Furthermore, the difficulties in coordination persist even though the

\footnotetext{
${ }^{49}$ Ibid., p. 54-68.

50 Ibid., p. 18.

51 Ibid., p. 7-17.

${ }^{52}$ See the Decision of the Minister of Environment No. 206/2005 on the Clean Development Mech-

53 See President Regulation 20084 (Indonesia) on the National Board on Climate Change.

54 President Regulation 200846 (Indonesia) on the National Board on Climate Change, consider-
} anism. ation c.

55 See President Regulation 200846 (Indonesia) on the National Board on Climate Change, art 3.

56 Jimly Asshiddiqie, "Hubungan Antar Lembaga Negara Pasca Perubahan UUD 1945" ("Relation Between State Body Post 1945 Constitution's Amendment"), presented in the Focus Group Discussion of National Defense Institution, 15 December 2010, (The Constitutional Court, 2010), p. 11.

57 Ibid.

58 See Constitution (Indonesia) art 17 (1) to (4). 
members of the Board are the President and the Ministers. ${ }^{59}$ In the absence of a specific law that addresses climate change, each department introduces policies that address their respective sectors. A policy introduced by a department will reflect sectoral policies and regulations, as the Constitution guarantees that each of the Ministries is responsible for certain areas of governance. ${ }^{60}$ This situation gives rise to uncoordinated policies and regulations, which increases the possibility of contradictions between these policies or regulations.

Accordingly, while these initiatives demonstrate the commitment of the national government to undertake climate efforts under the Convention, they face other domestic challenges, especially in relation to coordination between various sectors. These challenges suggest that even if the Convention faces coordination challenges at the national level, more challenges will emerge when dealing with lower government units under the context of decentralisation.

\section{The Decentralisation Model and International Agreement}

Because of decentralisation, the national government faces difficulties in directing lower government units to legally and politically observe the Convention rules. This is particularly the case in regard to the use of Indonesia's natural resources.

\section{A. The Background to Indonesia's Decentralisation}

Indonesia's decentralisation reform has an economic and political background that can constrain the national government in undertaking climate efforts. Economic factors generated political pressures regarding the gaining of political power from the national government. The combination of these economic and political factors helped to initiate decentralisation reform.

Economically speaking, under the Soeharto regime (1966-1998), the social and economic structure benefited the national government. Rachbini explains that during the New Order Regime, only a limited number of businessmen had wide access to bank credits. Others, especially small and medium sized entrepreneurs, had limited access. ${ }^{61}$ At the same time, the distribution of credits was geographically unequal. The distribution of bank credits focused on Java Island, particularly in the capital Jakarta. During the New Order regime, the Eastern part of Indonesia received only 5 percent of the total national credits. ${ }^{62}$

Furthermore, government tax income from all over Indonesia, which was intended to be shared as part of the development fund for the regions, was also distributed unequally. Mubyarto suggests that the New Order regime tried to centre development and industrialisation in Java Island. As a result,

\footnotetext{
${ }^{59}$ See President Regulation 200846 (Indonesia) on the National Board on Climate Change, art 4.

${ }^{60}$ See Constitution (Indonesia) art 17 (3).

61 Didik J. Rachbini, Politik Ekonomi Baru: Menuju Demokrasi Ekonomi (New Political Economy: Towards Democratic Economy), (Grasindo, Jakarta, 2001), p. ix.

${ }^{62}$ Ibid.
} 
the economic gap between Java and other regions was very wide. ${ }^{63}$ In 1970, Java Island, which was inhabited by 60 per cent of Indonesia's population, was 30-35 per cent poorer than other islands. Interestingly, by the beginning of 1990, Java's economy was performing 30-35 per cent better than the other Islands. ${ }^{64}$

This economic gap resulted in social and political problems. People from areas that significantly contributed to the Indonesian economy, such as Aceh, Papua, Riau, Kalimantan and other areas, were not satisfied with the national government policies. Natural resources in these areas were exploited extensively, but the benefits from the resources did not contribute significantly to the economy in these areas. ${ }^{65}$

After the fall of the Soeharto regime, many regions with valuable natural resources demanded a greater role in managing their local affairs and a greater share in the revenue from their natural resources ${ }^{66}$ The freedom movements that occurred in several parts of Indonesia created new democratic pressures for the regions to gain governmental power, and the national government undertook steps to meet this demand by decentralising governmental power ${ }^{67}$ The national government hoped that the sharing of power would reduce separatist sentiments. ${ }^{68}$ The social and political problems caused by the economic disparity were worsened by the economic crisis in Asia in 1997. Lindsey argues that the failure of the New Order regime to provide transparent and predictable administration contributed to the catastrophic scale of the economic crisis in Indonesia. The extraordinary political circumstances following the economic crisis resulted in the fall of the Soeharto regime in 1998, which helped to establish decentralisation efforts. ${ }^{69}$

Amidst this social, economical and political background of decentralisation, the dependence of the Convention on political support raises challenges. The national government cannot simply guide lower government units to undertake climate efforts.

\section{B. Indonesia's Decentralisation Model: Institutional Arrangement}

The institutional set-up and sharing of authority in Indonesia's decentralised context also creates challenges for the national government in

${ }^{63}$ Mubyarto, "Otonomi Daerah dan Ekonomi Kerakyatan" ("Local Autonomy and Democracy Economy") in Bonar Simorangkir et al (eds), Otonomi atau Federalisme: Dampaknya terhadap perekonomian (Autonomy or Federalism: Effects to Economy Condition), (Pustaka Sinar Harapan and Suara Pembaruan, Jakarta, 2000) 34, p. 36.

64 Ibid.

65 Albert Situmorang, "Sejarah Pemberontakan di Indonesia: Ketidakpuasan Rasionalisasi" $<$ http://www.indonesia-house.org/archive/060603Sejarah pemberontakan.htm> at May 1st 2010.

${ }^{66}$ Ida Aju Pradnja Resosudarmo, "Closer to People and Trees: Will Decentralisation Work for the People and the Forests of Indonesia?" (2004) 16 (1) European Journal of Development Research, 110, p. 111.

${ }^{67}$ SMERU, “Indonesia's Decentralisation Policy: initial experiences and emerging problems" (a paper prepared for the third EUROSEAS Conference panel on Decentralisation and Democratization in Southeast Asia, September 2001), p. 2.

${ }^{68}$ Ibid.

${ }^{69}$ Tim Lindsey, "From Rule of Law to Law of the Rulers-to Reformation?" in Tim Lindsey (Ed) Indonesian Law and Society, (Federation Press, NSW, Australia, 1999) 11 p. 19. 
effectively coordinating lower government units.

\section{Governmental Arrangement}

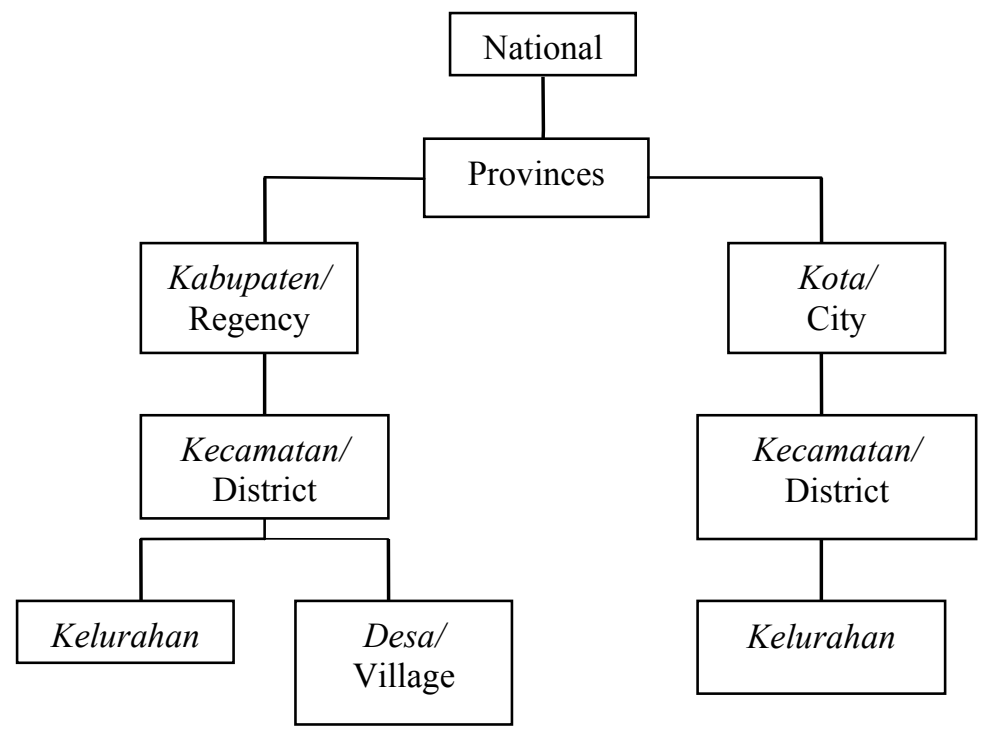

Figure 1. The administrative arrangement in Indonesia

Generally, the decentralised governmental arrangement focuses on local/city governments and not provincial governments. Governors, elected in each province, have a dual function. ${ }^{70}$ They not only act as the heads of their autonomous regions but they also retain a hierarchical relationship with the central government. ${ }^{71}$ In the latter position, they are considered agents of the national government who coordinate local government policies. This focus was a result of fear of national disintegration from separatist and secessionist movements. ${ }^{72}$ A province, as a larger administrative unit, might consequently form a larger separatist group. Some claim that by focusing on local governments, the national government gains benefits, because the national government bureaucrats have greater influence, compared to the influence of the provincial governments, over the local governments. ${ }^{73}$

The United Nations Development Programme (UNDP) suggests that

${ }^{70}$ Regional Government Act (Indonesia) 2004 32, art 10 (5) b.

71 Norio Usui and Armida Alisjahbana, "Local Development Planning and Budgeting in Decentralized Indonesia: Update" (Paper presented to the international symposium on Indonesia's Decentralisation Policy: problems and policy Directions, September 4-5, 2003), p. 2.

72 United Nations Development Programme (UNDP) Indonesia, "The Missing Link: the Province and its Roles in Indonesia's Decentralisation," (May 2009) 5, Policy Paper, p. 5.

${ }^{73}$ Ehtisham Ahmad and Ali Mansoor, "Indonesia: Managing Decentralization (2002), IMF Working Paper, at 5. 
Indonesia's decentralisation model, in focusing on the local government, creates a disconnection between the provincial government and local/city governments. ${ }^{74}$ The administrative hierarchical relation between the national government and lower government units (see Figure 1) differs from the functional hierarchy shown in Figure $2 .^{75}$

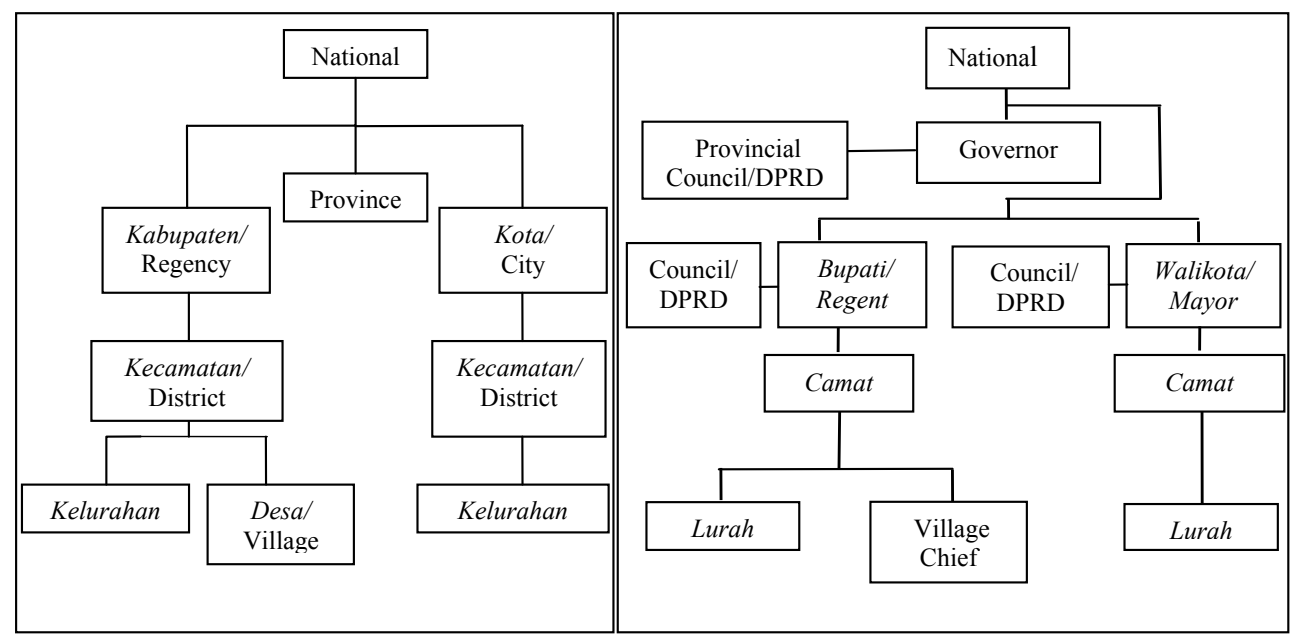

Figure 2. Functional Hierarchy

Figure 2 shows that the position of the province and regencies/cities is similar, in that they all receive power directly from the national government. In this sense, provincial and regency/city governments all act as autonomous units. As a consequence, the provinces have no links with the regency and city governments. This structure occurs because decentralisation focuses on regencies and cities, not provinces.

\section{The Sharing of Authority between Different Levels of Governments}

The decentralisation reform requires the sharing of power between different levels of government. The initial Decentralisation Act after the fall of the Soeharto regime (Act No. 22/1999) shared governmental authority simply based on administrative borders. After the revocation of this Act, different levels of government now share their authority based on legal provisions, although several sectoral laws still apply the administrative border scheme in determining the share of authority. This makes the sharing of governmental power complicated. The decentralisation regime is not the only legal source that determines the authority of different levels of government. Sectoral laws

${ }^{74}$ UNDP, see note 74, p. 5.

${ }^{75}$ Source: UNDP Indonesia, ibid., p. 11. 
and regulations also determine the share of the governmental authority.

Act No. 22/1999 granted significant power to provincial and local/city governments, based on the administrative border scheme. Except for authority over international politics, defence, the judiciary, fiscal and monetary affairs, and religious affairs, the provincial and local governments could implement their authority over other governmental sectors. ${ }^{76}$ Administrative borders determined the sharing of power of different levels of government. A provincial government had authority over affairs involving two or more local governments, ${ }^{77}$ with an administrative border of up to 12 nautical miles. ${ }^{78} \mathrm{~A}$ local government had power to manage natural resources in their area, up to 4 nautical miles. ${ }^{79}$

This governmental sharing model affected the sharing of authority under sectoral laws. In the forestry sector, the Regent, the Governor and the Minister of Forestry could issue a license based on the administrative border scheme ${ }^{80}$ In the mining sector, the same administrative border scheme was applicable. Shortly after the implementation of decentralisation policy, authority over the mining sector changed ${ }^{81}$ Local governments can now issue mining concessions within their administrative areas (up to 4 nautical miles) and provincial governments can issue concessions when the proposed areas involve two or more areas of local governments, or within 4 to 12 nautical miles. Further, the Ministry of Energy and Mineral Resources could issue mining concessions when the area involves two or more provincial areas or outside the 12 nautical miles territory. ${ }^{82}$

In 2004, Act. No 32/2004 revoked Act No. 22/1999 and remains in force. This new Act provides a more complicated governmental sharing regime. It grants rights to the provincial and local/city governments to implement their autonomy. Except for the six excluded authorities, ${ }^{83}$ other authorities are under the autonomy of the lower government organs. However, the Act also states that besides these six authorities, the national government can implement the other authorities itself, transfer authority to the Governors, or order the provincial, local/city, and village governments to run its authority. ${ }^{84}$ The term "other authorities" is considered as "concurrent authorities," which are shared by all levels of governments ${ }^{85}$ and governed by the Government Regulation No. 38.2007 on the Sharing of Authority between the National, Provincial
${ }^{76}$ Regional Government Act (Indonesia) 1999 22, art 7 (1).
77 Regional Government Act (Indonesia) 1999 22, art 9 (1).
${ }^{78}$ Regional Government Act (Indonesia) 1999 22, art 3.
${ }^{79}$ Regional Government Act (Indonesia) 1999 22, art 10 (3).
${ }^{80}$ Government Regulation 200234 (Indonesia) on Forestry Management Regulation, art 38.
${ }^{81}$ Government Regulation 200175 (Indonesia) on the Second Amendment of the implementation of the Mineral Act No 11/1967, p. the consideration.

${ }^{82}$ Government Regulation 200175 (Indonesia) on the Second Amendment of the implementation of the Mineral Act No 11/1967, art 1.

${ }^{83}$ These six authorities are (1) international politics; (2) defence; (3) security; (4) judicial power; (5) national fiscal and monetary; and (6) religious affairs. See Regional Government Act 2004 32, art 10 (3).

${ }^{84}$ Regional Government Act 2004 32, art 10 (5).

85 The elucidation explains that concurrent authorities are the authorities that can be run by the national, the provincial and local government due to the nature of authorities. See the elucidation of the Regional Government Act 2004 32, part I, 3. 
and Local/City Governments. ${ }^{86}$ As a result, the national government actually retains all government authorities, and the transfer of authority to lower government units is subject to the discretion of the national government. ${ }^{87}$ The President enacts a government regulation to implement an $\mathrm{Act}^{88}$ or a decision of the Supreme Court, ${ }^{89}$ based on a draft proposed by the relevant ministries. ${ }^{90}$

Generally, Government Regulation No. 38/2007 provides power to the national government to set up norms and policies in the forestry sector. The provincial government is given the role of supervising national forestry policies of provincial scale. The local/city governments have most of the policy implementing power, such as dealing with the control of mining operations and environmental assessments. ${ }^{91}$ In essence, the introduction of the new decentralisation laws has tried to reduce the role of the administrative border scheme in determining the sharing of governmental authority between different levels of government. This regulation not only employs the administrative border scheme to share governmental authority but also uses other schemes. For instance, national government shares the authority to issue forestry licenses with provincial and local governments, based on legal provisions related to decentralisation laws. Those who want to use forest timber must obtain a license from the Minister of Forestry, while others who want to pick timber products in forests can obtain a license from the Governor or Regent/Mayor. ${ }^{92}$ Government Regulation No. 38/2007 distinguishes the meaning of use which implies extraction, and pick which means collection, in determining the kind of license issued. The difference between the two terms refers to the scale of timber log harvesting.

In sectoral laws and regulations, legal provisions and administrative borders are both used to determine the sharing of authority. The Forestry Regulation, for instance, shares the authority to issue a license based on the type of licens $\mathrm{e}^{93}$ and the administrative border. ${ }^{94}$ By comparison, in the mining sector, the administrative border still functions as the basis for sharing authority. The Mineral Act provides significant authority for the provincial and local governments over the issuance of mining licenses based on the administrative border scheme. ${ }^{95}$

A comparison of the forestry and mining regimes suggests that the

${ }^{86}$ This Regulation is the implementing regulation of Regional Government Act 200432 (Indonesia).

${ }^{87}$ See also Butt: "legally speaking, the central government can continue to regulate any matter over which regional governments also have jurisdiction". Simon Butt, "Regional Autonomy and Legal Disorder: the Proliferation of Local Laws in Indonesia" (2010), Singapore Journal of Legal Studies, 1, p. 7.

${ }^{88}$ See the Forming of Laws Act 201112 (Indonesia), art 1 (5).

${ }^{89}$ See the Forming of Laws Act 201112 (Indonesia), art 28 (2).

${ }_{90}$ See the Forming of Laws Act 201112 (Indonesia), art 27.

${ }^{91}$ Government Regulation 200738 (Indonesia) on the Sharing of Authority between the National Provincial and Local/City governments, p. attachment BB.

92 Government Regulation 200738 (Indonesia) on the Sharing of Authority between the National, Provincial, and Local governments, the Forestry Sector Attachment AA, number 34.

${ }^{93}$ See for Instance, Government Regulation 20076 (Indonesia) on the Management and the Usage of Forest, art 60.

${ }^{94}$ See for instance, Government Regulation 20076 (Indonesia) on the Management and the Usage of Forest, art 61.

${ }_{95}$ Mineral and Coal Mining Act 20094 (Indonesia), art 6, 7 and 8. 
legal provisions and administrative border scheme are both applicable bases for the sharing of authority. As a result, the particular authority of different levels of government over a variety of sectors will depend on the sectoral laws and regulations, not merely the decentralisation regime. This can increase the possibility of contradictory policies and interpretations regarding the authority of different levels of governments.

\section{The Effects of Decentralisation on the Forestry Sector}

Indonesia's decentralisation may have reduced tensions arising in the regions. By the sharing of power, the extent of separatist sentiments which prevailed in many provinces was reduced. ${ }^{96}$ However, decentralisation has generated environmental degradation, which in turn can result in an increased rate of GHG emissions. This can be a result of the existence of "optional authorities" that are shared by different levels of governments.

Many have identified the effects of decentralisation on the forestry sector. The underlying causes of deforestation are varied. From an economic perspective, Barr et al suggest that the euphoria of decentralisation caused district officials to issue large numbers of "small-scale timber extraction" and forest conversion permits that aim to impose new types of fees and royalties on "log harvesting" as a means to generate "regionally-generated revenues." ${ }^{\prime 97}$ At the same time, social and political causes of deforestation have also emerged. Bertrand suggests that following the fall of the regime, local communities have tried to transform the centralistic forest management under the New Order Regime into a greater freedom to reclaim the forest areas on which they relied on for daily living. ${ }^{98}$ Under this situation, the national government may have lost its dominant control over natural resources. ${ }^{99}$ Decentralisation has created legitimate and illegitimate procedures for gaining benefits from natural resources because of the involvement of various actors. ${ }^{100}$

The underlying cause of the effects of decentralisation on the forestry sector is the failure to determine the exact nature of authority. Indonesia's decentralisation recognises the obligatory and optional authorities of the provincial and local/city governments. ${ }^{101}$ The Decentralisation Act lists the obligatory authorities, which includes environmental control. Optional authorities also grant rights for the regions to determine whether they will maximise the local potential to improve the people's welfare according to the characteristics of each region. ${ }^{102}$ The existence of the optional authorities is crucial for the decentralisation scheme as it provides a flexible term that result in a wide interpretation of authority.

${ }^{96}$ SMERU, see note 70, p. 2.

${ }_{97}$ Christopher Barr and others, Decentralisation of Forest Administration in Indonesia: Implications for Forest Sustainability, Economic Development and Community Livelihoods, (CIFOR, Bogor, 2006) at 79 .

${ }_{98}$ Jacques Bertrand, "Indonesia's Quasi-Federalist Approach: Accommodation amid Strong Integrationist Tendencies," (2007) 5 (4), International Journal of Constitutional Law, 576, at 2.

${ }_{99}$ John F McCarthy, "Local Voice in Shifting Modes of Decentralised Resource Control in Central Kalimantan, Indonesia" (2007) 65, Management in Asia-Pacific Working Paper, at 6.

${ }^{100}$ Ibid.

${ }^{101}$ Regional Government Act 200432 (Indonesia), art 11 (3).

102 Regional Government Act 200432 (Indonesia), art 13 (2). 
In the management of natural resources, these optional authorities are critical as the national, provincial and local governments share their authorities. ${ }^{103}$ Although the Decentralisation Act tries to limit the flexibility of the optional authorities by introducing a requirement to refer to laws and regulations, different interpretations on optional authority may still emerge. For example, a Regent (the head of a Kabupaten or regency), may see the potential of a natural resource in a region, and decide to invest in it. Natural resource exploitation may then take place. Such a decision can contradict with national government policy. Rusli and Duek suggest that decentralisation meets the demands of the provincial and local governments to gain revenue from natural resources. Indonesia's decentralisation facilitates their desires to implement their decentralised authority. McCarthy advises that local governments adopt a regulatory system which "creatively" uses the national legal system for local benefits. ${ }^{\text {[ }}$

\section{Treaty and Lower Government Units}

Under international law, once a state concludes an international agreement, "a treaty is binding upon each party in respect of its entire territory." ${ }^{04}$ Yet, the Vienna Convention on the Law of Treaties does not specify how a state implements an international agreement in its domestic jurisdiction. ${ }^{105}$ Thus, the state parties should ensure that obligations arising from an international agreement have domestic effect, where all state organs must comply with the national law in order to facilitate the fulfilment of the obligations raised by the international agreement. ${ }^{106}$ In fact, Indonesia requires lower government units to perform rules of international agreements. However, this requirement is not firm.

The Decentralisation Act (32/2004) does not specifically refer to any obligation for lower government units to comply with international agreements in any of its rules. This can only be found in the elucidation provision of the Act, which classifies the fulfilment of the national commitment to international agreements as obligatory tasks of the lower government units. ${ }^{107}$ As a result, the requirement to perform an international agreement exists, not as a legal rule but as an explanation of a term in the elucidation of the Act.

Furthermore, in several provinces where special autonomy applies, such as Aceh, Papua and West Papua, different arrangements exist. In Aceh, although the national government retains control over international politics, the Government of Aceh has considerable power. The Aceh government Act states that where the national government considers a plan to conclude an international agreement that relates only to Aceh, the Aceh Provincial Legislative Council (Dewan Perwakilan Rakyat Aceh/DPRA) must be consulted. ${ }^{108}$

\footnotetext{
${ }_{103}$ Regional Government Act 200432 (Indonesia), art 17.

104 Vienna Convention on the Law of Treaties (1969), art 29.

105 Anthony Aust, see note 4, p. 179.

106 Ibid.

107 The Elucidation of Regional Government Act 200432 (Indonesia) on art 11 (3) c.

108 Aceh Government Act 200611 (Indonesia), art 8 (1).
} 
This consultation requirement, however, has a political character rather than a legal one. When the DPRA fails to consider the relevant plan within 45 days, the national government can proceed regardless. ${ }^{109}$ The absence of consideration might suggest that the DPRA agrees with the proposed plan. Yet, political tension arises when the DPRA proposes a modification to the plan but the national government cannot accommodate the modification. In this sense, musyawarah (consultation) is the only solution. ${ }^{110}$ However, no time limit is set for the consultation process and no alternative solution is provided if both sides fail to agree. As a result, an impasse may emerge: the national government cannot proceed with the proposed plan, but the DPRA cannot reject the plan either until both sides achieve a consensus. This scenario also applies to administrative arrangements. When the national government is considering a national administrative policy that directly relates to the Aceh Government, the Governor of Aceh needs to be consulted. ${ }^{111}$ In the event the national government cannot accommodate the Governor's view, consultation is the only solution. ${ }^{112}$

Moreover, the provinces of Papua and West Papua also have special autonomy. The special autonomy in these two provinces has granted authority over all affairs to the provincial government, except authority over foreign politics, national defence and security, national fiscal and monetary affairs, religious affairs, and the court, along with "other affairs" that are specifically regulated by other Indonesia's laws. ${ }^{113}$ When the national government intends to conclude an international agreement that only relates to the interests of the Papua and West Papua provinces, the Governors' consideration is required. ${ }^{114}$ Unlike the procedure for Aceh's special autonomy scheme, which is governed by a Presidential Regulation, the procedure for the Governors of Papua and West Papua to consider proposed international agreement initiated by the national government is governed by a Special Provincial Regulation (Peraturan Daerah Khusus/Perdasus) enacted by each of these provinces. ${ }^{115}$ However after close examination, as at February 2012, no Perdasus has been enacted

109 President Regulation 200875 (Indonesia) on the Procedure on Providing Considerations for a Plan of International Agreement, a Plan to Form Laws and Administrative Policy Relating Directly to the Aceh Government, art 3 (2), (3) and (4).

110 President Regulation 200875 (Indonesia) on the Procedure on Providing Considerations for a Plan of International Agreement, a Plan to Form Laws and Administrative Policy Relating Directly to the Aceh Government, art 4 (3).

111 President Regulation 200875 (Indonesia) on the Procedure on Providing Considerations for a Plan of International Agreement, a Plan to Form Laws and Administrative Policy Relating Directly to the Aceh Government, art 7 (1).

112 President Regulation 200875 (Indonesia) on the Procedure on Providing Considerations for a Plan of International Agreement, a Plan to Form Laws and Administrative Policy Relating Directly to the Aceh Government, art 9 (3).

113 Special Autonomy for Papua Province Act 200121 (Indonesia), art 4 (1). The phrase "other affairs" provides wide possibilities for interpretation. When the authority of the Governments of Papua and West Papua based on this Act is limited by the other Indonesia's Act, which one will prevail? Potential conflict of interpretation can easily arise.

114 Special Autonomy for Papua Province Act 200121 (Indonesia), art 4 (6).

115 Special Autonomy for Papua Province Act 200121 (Indonesia), art 4 (9). A special Papua Provincial Government Regulation (Peraturan Daerah Khusus/Perdasus) in the Papua and West Papua Province is specially enacted to implement an order of the Special Autonomy Act. A Perdasus is different from a Papua Provincial Government Regulation (Peraturan Daerah Provinsi/Perdasi) that is enacted to implement the authority of the Papuan Province pursuant to laws and regulations. See art 1 (i) and (j). 
in the both provinces that specifically addresses the terms and conditions for the Governors to provide consideration on the proposed international agreement. As a result, the requirement for consideration is still subject to multiple interpretations.

\section{The Burdens of Decentralisation}

Decentralisation creates burdens for the national government in initiating climate efforts under the Convention. These burdens are associated with coordination problems, legality issues and challenges relating to Indonesia's social and political background.

\section{A. International Political Arrangement Generates Burdens}

Indonesia's decentralisation laws suggest that international politics is the exclusive domain of the national government. This exclusivity isolates lower government units from international politics. In the context of decentralisation, this approach is sometimes problematic as it generates constraints for the relationship between national government and lower government units.

The isolation of lower government units from international politics suggests a centralist approach that reduces the participation of lower government units. Fundamentally, decentralisation requires the intergovernmental or political transfer of powers and responsibilities to an elected local government, which exercises a significant measure of local autonomy. ${ }^{116}$ Such a transfer will bring governments closer to the consumers of public services, and any governmental policy will become closely controlled by the citizens. ${ }^{117}$ Under the centralist approach, however, public participation will be low. The centralist approach creates a disconnection between international and domestic politics. Local government, which is closer to people, has no influence in any international negotiations. This can become a burden when the national government negotiates a treaty that can affect the authority of lower government units.

Certain international agreements can still work despite this disconnection, especially those that do not directly relate to the concurrent authorities that are shared by different levels of government. For instance, Indonesia's ratification of the 1963 Vienna Convention on Consular Relations ${ }^{118}$ does not directly relate to the authority of lower government units. Rather, the Vienna Convention ${ }^{119}$ emphasises privileges and immunities for diplomats, which facilitates the performance of functions by the consular posts on behalf of their respective states. ${ }^{120}$ This emphasis suggests that it is the national

${ }^{116}$ Nick Devas, “Indonesia: what do we mean by decentralisation?” (1997) 19, Public Administration and Development, p. 2.

117 Ibid.

118 Indonesia validates the 1963 Vienna Convention by Act No. 1/1982.

119 Vienna Convention on Consular Relations (opened for signature 24 April 1963, entered into force 19 March 1967).

120 Vienna Convention on Consular Relations (opened for signature 24 April 1963, entered into 
government of each state that plays a significant role in the implementation of the Vienna Convention at the domestic level. As a result, the role of the lower government units is not significant.

By contrast, when an international agreement involves the sharing of authority between different levels of government, as is the case for the Convention on climate change, problems can emerge. While Indonesia has become a party to the Convention, the lower government units have committed to actions that contribute to Indonesia's high rate of GHG emissions from deforestation. Contradiction between international politics and domestic politics exists.

This contradiction is not merely political but also legal. For instance, Indonesia's commitment to the UNFCCC may require the national government to alter the authority of the provinces and local government. Yet, the exploitation of forests based on the granting of timber concessions by local government has alarmingly increased deforestation. At this point, the action of local government contradicts with the national government's legal commitment under the Convention.

Therefore, the arrangement of international politics under Indonesia's decentralisation can become a burden for the implementation of the UNFCCC. When fulfilment of an international commitment does not require the engagement of lower government units, domestic politics are not significant. In the context of the UNFCCC in Indonesia, though international politics is the exclusive domain of the national government, the national government depends on lower government units to fulfil international commitments.

\section{B. Coordination Problems}

Because decentralisation focuses on local/city governments, coordination between different levels of government can be a huge challenge. This challenge is due to the national government's capacity to control local government action and the wide authority of local governments to introduce local policies.

The capacity to control local government action can raise coordination problems. Focusing decentralisation on local/city governments requires the national government to coordinate its policies. The role of provincial governments is limited as the local/city governments receive authority directly from the national government. This condition is problematic because Indonesia consists of more than $300 \mathrm{local} /$ city governments.

Coordination between the different levels of government emphasises the vital role of the provincial governments. Governors not only act as the heads of their autonomous regions but they also retain a hierarchical relationship with the central government. ${ }^{121}$ This dual function of Governors can facilitate the national government in reaching local government level. However, this dual

force 19 March 1967) preamble: "Realizing that the purpose of such privileges and immunities is not to benefit individuals but to ensure the efficient performance of functions by consular posts on behalf of their respective States."

${ }^{121}$ Norio Usui and Armida Alisjahbana, see note 73, p. 2. 
function creates a dilemma. As the head of autonomous regions, Governors need to consider the political dynamics within their provinces, as they are directly elected in a general election. ${ }^{122}$ As a result, potential conflicts of interest may emerge, because Governors will need to choose who they are answerable to: the national government or their constituents. When a Governor is from the same political party as the ruling party at the national level, the situation may not be very complicated. The Governor will most likely follow national government policy. However, when the Governor is from the opposition party at the national level, the potential of disobedience is high. The situation is even more complicated when a Regent is also from a political party which differs from the ruling parties at both the national and provincial levels.

Moreover, the sharing of governmental power according to the various governmental regulations, and based on a combination of the administrative border scheme and legal provisions, can worsen policy coordination problems. Decentralisation allows the provincial and local/city governments to introduce Local Government Regulations (Peraturan Daerah/Perda). ${ }^{123}$ Perda are enacted to implement higher laws and regulations, with consideration given to the specific characteristics of each region. ${ }^{124}$ Perda provide opportunities for provincial and local/city governments to introduce local policies, so as long as a Perda does not contradict higher laws and regulations. ${ }^{125}$ Given the variety of standards and legal provisions used by higher laws and regulations to determine the sharing of governmental authority, the risk of contradiction between policies can be high. During the process of enacting Perda, which must consider the various standards and legal provisions set by higher laws and regulations, different interpretations can emerge relating to the authority of the provincial and local/city government. Contradiction with higher laws and regulations is thus highly likely. In addition, the opportunity for Perda to reflect the special characteristics of each region suggests it is likely that local policies will contradict with national policies. The extent of the possibilities for contradiction correlates with the high number of Perda that are under the review of the national government. According to the Minister of Internal Affairs, the Ministry finished evaluating 4500 Perda in July 2011, where 175 were annulled and the rest were recommended for amendment. As at October 2011, 9000 problematic Perda remained to be evaluated by the Ministry. ${ }^{126}$

The potential contradiction of Perda with higher law and regulation is worsened by the problematic mechanism and practice used to evaluate Perda. Basically, the ability for lower government units (provinces and local/ city governments) to adopt Perda is equipped with a review mechanism that employs bureaucratic and judicial processes. In bureaucratic process the position of the national government is central. 7 days after the enactment, a Perda should be received by the national government ${ }^{127}$ for a review. When

122 Regional Government Act 200432 (Indonesia), art 24 (5).

${ }^{123}$ A Perda can be enacted by the provincial government or local/city government by an agreement of the executive and legislative. See the Forming of Laws Act 201112 (Indonesia), art 1 (7) and (8).

${ }^{124}$ Regional Government Act 200432 (Indonesia), art 136 (3).

125 Regional Government Act 200432 (Indonesia), art 136 (4).

126 See Kontan, "Evaluasi 9.000 Perda bermasalah digelar sampai 2014" ("Evaluation of 9.000 Problematic Perda held Until 2014"), (17 Oktober 2011), <http://nasional.kontan.co.id/news/evaluasi9.000-perda-bermasalah-digelar-sampai-2014-1> at 6 June 2012.

127 Regional Government Act 200432 (Indonesia), art 145 (1). 
the national government perceives that the Perda is against public interests or/and contradicts higher laws and regulations, ${ }^{128}$ it can cancel the Perda through a Presidential Regulation. ${ }^{129}$ This review process takes approximately 60 days. ${ }^{130}$ The relevant local government or provincial government has only seven days to revoke the Perda, ${ }^{131}$ or it can challenge the Presidential Regulation in the Supreme Court. ${ }^{132}$

For some Perda, a pre-enactment-approval requirement applies and the process follows the governmental hierarchy. At the provincial level, a draft Perda that sets an annual budget requires a pre-approval from the Ministry of Home Affairs. ${ }^{133} \mathrm{~A}$ draft Perda that aims to impose local tax and charges, requires coordination with the Ministry of Finance, while a draft Perda that arranges local spatial planning requires coordination with the relevant Ministries. ${ }^{134}$ For the local government level, the similar scenario applies, though the role of the relevant ministries is replaced by governors. ${ }^{135}$

An annual budget Perda is reviewed within 15 days by higher level of governments. ${ }^{136}$ When the Perda (provincial level) is considered by the national government through the Ministry of Home Affairs (in coordination with relevant ministries) as not against public interests and higher laws, it will get an approval and can be enacted by Governor. ${ }^{137}$ On the contrary, when a provincial Perda is considered as against the interests of public and higher laws and regulations, the Governor and Provincial Council have seven days to make amendments. ${ }^{138}$ Failure to do so will give the authority for the Ministry of Home Affairs to cancel the plan to enact the Perda, which directly applies the previous year budget. ${ }^{139}$ The similar arrangement applies to local/ city governments Perda: the Governor has the right to review, approve or disapprove Perda in the local/city governments' level. ${ }^{140}$

This bureaucratic review process is problematic. Butt, ${ }^{141}$ for instance, identifies that the national government through the Ministry of Home Affairs has limited capacity to evaluate Perda because the number of problematic Perda was very high while the Ministry has limited personnel. As a result, many Perda that were annulled cannot fulfil the 15 days time limit. Many were annulled after two years of under review. ${ }^{142}$ In addition, the absence of sanctions for local governments that refuse to submit their new Perda for evaluation provides them a wide possibility to bypass the bureaucratic review mechanism. ${ }^{143}$

\footnotetext{
${ }^{128}$ Regional Government Act 200432 (Indonesia), art 145 (2).

${ }^{129}$ Regional Government Act 200432 (Indonesia), art (3).

${ }^{130}$ Regional Government Act 200432 (Indonesia), art 93).

131 Regional Government Act 200432 (Indonesia), art (4).

132 Regional Government Act 200432 (Indonesia), art (5).

133 Regional Government Act 200432 (Indonesia), art 185.

${ }^{134}$ Regional Government Act 200432 (Indonesia), art 189.

135 Regional Government Act 200432 (Indonesia), art 186.

${ }^{136}$ Regional Government Act 200432 (Indonesia), art 185, 186 and 189.

137 Regional Government Act 200432 (Indonesia), art 185 (3).

${ }^{138}$ Regional Government Act 200432 (Indonesia), art 185 (4).

139 Regional Government Act 200432 (Indonesia), art 185 (5).

${ }^{140}$ Regional Government Act 200432 (Indonesia), art 186 (4), (5).

141 Simon Butt, see note 89, p. 1.

142 Ibid., p. 12.

143 Ibid., p. 11.
} 
Furthermore, the mechanism to review of Perda also has judicial channel. When the National Government through a Presidential regulation decides to revoke a Perda, ${ }^{144}$ the relevant Province or local/city government can challenge the decision in the Supreme Court. ${ }^{145}$ This can result in the revocation of the Presidential Regulation. ${ }^{146}$ Citizens can also challenge Perda in the Supreme Court. In Indonesia's legal system, judicial review can take place in the Constitutional Court when it involves an act, while lower sources of laws such as Government Regulation, Presidential Regulation, Perda (Province and local/city governments) can only involve in a judicial review in the Supreme Court ${ }^{147}$ through lower courts. ${ }^{148}$

The existence of this judicial process mechanism may provide opportunities for lower government units to challenge decisions of the National Government that revoke a Perda. At the same time, citizens can directly challenge Perda that burden them. However, while this process is very critical on disputes over Perda, the process in the Supreme Court might be flawed. The Supreme Court has not as yet effectively performed its Perda review function due to the time limit that applies to the review of Perda (180 days after enactment) and the court's limited capacity to consider the substance of Perda. ${ }^{149}$ In addition, the two review mechanisms have only focused on the review of Perda that aims to impose local tax and levies, but not for Perda that related to, for instance, the violation of human rights. ${ }^{150}$

\section{Vague Obligations to Fulfil International Commitments}

Indonesia's legal system does not firmly establish a link between the Convention and lower government units. Obligation on lower government units to fulfil commitments under international agreements is vague.

The fulfilment of international commitments is not a legal obligation but only a formal interpretation of the term "obligatory authority" in the Decentralisation Act. The Decentralisation Act does not define the term "obligatory authority." Yet the Act lists obligatory authorities for the Provincial and Local/City governments. These authorities generally include development planning and control, environmental control, and providing basic services and infrastructure to the community. ${ }^{151}$ This Act does not mention anything about international commitments. However, in its elucidation, the fulfilment of international commitment is included. The elucidation provision of Art 11(3) explains the term "obligatory authority" as comprising fundamental tasks that relate to the fulfilment of rights and basic services for the citizen.

144 Regional Government Act 200432 (Indonesia), art 145 (3). For a Provincial Perda on Annual Budget, the Ministry of Home Affairs has the authority to cancel the Perda along with its Governor Regulation that implements the Perda on annual budget. See art 185. For local/city governments' Perda on Annual Budget, relevant Governors have the authority to cancel the Perda. See art 186.

145 Regional Government Act 200432 (Indonesia), art 145 (5).

146 Regional Government Act 200432 (Indonesia), art 145 (6).

147 The Forming of Laws Act 2011 12, art 9. See also the Supreme Court Act 1970 14, art 26 (1).

148 The Supreme Court Regulation on Judicial Review No. 01/2011, art 2.

149 For further discussion of the problem to review Perda in the Supreme Court, see Simon Butt, see note 147 .

150 Ibid., p. 4.

151 Regional Government Act 200432 (Indonesia), art 13 and 14. 
This includes the protection of constitutional rights, the protection of national interests, the welfare of the people, public safety and the unity of the state, and the fulfilment of national commitments to international agreements. ${ }^{152}$

This suggests that provincial and local governments should also observe international rules that the national government has committed to. This elucidation provision requires provincial and local government not to adopt policies that can contradict with international commitments agreed to by the national government. In this scenario, government units from the national level down to the local government levels are responsible for the fulfilment of the goal of the UNFCCC. As a result, although the provincial and local government can issue licenses for timber extraction, this authority is not without limitation. The issuance of timber extraction licenses can reduce forest cover, which can lead to an increase of emissions from deforestation, and therefore contradict with the goal of the Convention. The issuance of timber licenses should take into account Indonesia's commitment to the Convention.

However, this obligatory authority to fulfil international commitments is vague for the following reasons. First, this authority has a weak character. While the character is said to be obligatory, no sanction is applicable when a lower government unit introduces a policy that contradicts with the goal of the Convention. Fulfilment of the national commitment to the Convention may depend on lower government units, yet no legal obligation exists in the event of violation. The Decentralisation Act suggests that the fulfilment of an international commitment is the obligation of the lower government units but it creates no sanctions for non-compliance.

Second, the requirement for provincial and local governments to fulfil the national commitment to an international agreement as part of their obligatory authority is ambiguous. In Indonesia's legal system, the elucidation provisions of Acts only contain explanations of rules, ${ }^{153}$ which aim to provide a formal interpretation of the text of the rules. ${ }^{154}$ Regarding the term "obligatory authority," the elucidation of the Decentralisation Act explains that this term relates to the fulfilment of rights and basic services for citizens. ${ }^{155}$ However, when the elucidation elaborates on the kinds of obligatory authority, which includes the fulfilment of national commitments to international agreements, ${ }^{156}$ it introduces a norm. As a result, the elucidation exceeds its explanatory function, and the inclusion of the requirement for the lower government units raises a legitimacy problem.

The obligation of provincial and local governments to fulfil international commitments of the national government is not strong and can easily raise tensions among different levels of governments.

${ }^{152}$ See the elucidation on the article 11 (3) of Regional Government Act 200432 (Indonesia).

153 See the Forming of Law Act 102004 (Indonesia), art 47. After the revocation of this Act and replaced by Act No. 122011 (Indonesia), the function of the elucidation remains the same. See art 84 .

${ }^{154}$ Jimly Asshidiqie, Pengantar Hukum Tata Negara Jilid 1 (Introduction to Constitutional Law Part

1), (Sekretariat Jendral dan Kepaniteraan Mahkamah Konstitusi, Jakarta, 2006), p. 82.

${ }^{155}$ See Regional Government Act 200432 (Indonesia), the elucidation of the article 11 (3).

156 See Regional Government Act 200432 (Indonesia), the elucidation of the article 11 (3). 


\section{The Convention in Indonesia's Decentralisation}

Having only a soft legal obligation and facing legality issues in Indonesia's context, political commitments are central to the effective implementation of the Convention. Keohane and Raustiala advise that any international agreement on climate change requires political commitment. In democracies, political commitments that require public support are "exogenous" factors that determine the effectiveness of an international agreement at the domestic level. ${ }^{157}$ However, while political commitments are central, the national government faces difficulties in exerting such commitments for climate efforts due to domestic factors associated with the legal and political issues.

Indonesia's ratification procedure leaves open legality issues relating to the ratifying laws. The Ratifying Acts of the Convention and the Kyoto Protocol are not clear sources of law. Although taking the form of an Act, which is a valid legal source, these Ratifying Acts remain ambiguous. It is not clear whether they are an instrument of ratification or transformation. These legality issues have merely added to the problems of initiating climate efforts under the Convention and its Kyoto Protocol. The Convention only contains general principles and its Kyoto Protocol excludes Indonesia from any commitment to reduce GHG emissions. Such a situation suggests that the Convention and its Kyoto Protocol are ineffective legal instruments in Indonesia's legal system.

As the Ratifying Acts have faced legality issues, Indonesia's decentralised context exacerbates problems concerning the fulfilment of Indonesia's commitment to climate efforts. The national government does not have a valid legal provision which functions as the legal basis to direct lower government units to observe the Convention. The obligation for lower government units to fulfil the national commitment on the Convention and its Kyoto Protocol is vague. Neither valid rules exist nor can any sanction be imposed for lower government units that are non-compliant.

In this situation, political commitments become important. Support from lower government units and local actors can facilitate the fulfilment of national commitment to the Convention. However, gaining political support from local levels can be difficult. In the forestry sector, if fulfilling national commitments under the Convention limits the regions in gaining benefits from forest resources, political support will be reduced. After the fall of the Soeharto regime, local actors perceived it as the time for them to obtain their share of the benefits associated with forestry resources. ${ }^{158}$

The potential lack of political support for climate change mitigation efforts in the decentralisation context results from two logical consequences of Indonesia's decentralisation model. They are the arrangement of international politics under decentralisation and a necessity for the lower government units to increase development budgets.

Authority over international politics under decentralisation, which is exclusively the domain of the national government, denies the significance of local politics in the implementation of the Convention. The Constitution

\footnotetext{
${ }^{157}$ Robert O. Keohane and Kal Raustiala, see note 47, p. 2.
}

158 Christopher Barr and others, see note 99, p. 2. 
guarantees rights for the provinces, regencies and towns to regulate and administer matters of government on the basis of autonomy and the duty of assistance. ${ }^{159}$ In addition, the Decentralisation Act grants rights to lower government units to implement their regional autonomy as widely as possible in order to increase the welfare of society in their regions, ${ }^{160}$ based on the special characteristics of each province and region. ${ }^{161}$ These rights are also complemented by the establishment of optional authorities for provincial and local governments. Optional authorities include several sectors, such as agriculture, forestry, energy and mineral resources, tourism, industry, and trade and transmigration. ${ }^{162}$ In a region that is rich in natural resources, when the Regent perceives the potential of those resources to increase the welfare of society, it is highly likely the potential will be maximized irrespective of any international commitment.

The denial of local politics may also reduce the legitimacy of the national commitment to the Convention, given that participation by local actors is not possible. In certain situations, when an international agreement only requires the national government to take measures without engaging the regions, this lack of participation is not fatal. A requirement to submit a yearly report to the COP of the Convention, for instance, can be done by a ministry at the national level. However, when Indonesia aims to implement measures that directly involve the political dynamics of the regions, such as when limiting the use of forestry resources, participation of the regions prior to the conclusion of an international agreement is necessary. Such participation will increase the legitimacy of the national government policies.

The use of local politics for the sake of international politics actually exists in the special autonomies of Aceh, Papua and West Papua. Although, the authority of international politics remains in the national government, the requirement for national government to consult with lower government units on a plan for an international agreement does not isolate international politics from domestic politics. The consultation requirement can increase political participation by the regions. As a result, the concluded international agreement can have greater legitimacy when implemented in the three Provinces. However, difficulties can emerge when the national government intends to conclude an international agreement that contradicts with local politics in the Provinces.

Furthermore, lower government units need to seek adequate funds to support their new authority to provide better public services. The transfer of power from national government to lower government units requires an adequate budget to support their functions. Inoui and Alisjahbana suggest that in order for decentralisation to be effectively implemented, lower government units should be supported by adequate function to meet their new capacity, while function works properly when there is enough funding available. ${ }^{163}$

\footnotetext{
${ }^{159}$ Constitution (Indonesia), art 18 (2).

${ }^{160}$ Regional Government Act 200432 (Indonesia), art 2 (3)

${ }^{161}$ Regional Government Act 200432 (Indonesia), art 13 (2) and art 14 (2).

162 Government Regulation 200738 (Indonesia) on the Sharing of Authority between the National, Provincial, and Local governments, art 7 (4).

${ }^{163}$ Norio Usui and Armida Alisjahbana, see note 125, p. 3.
} 
These conditions indicate that in order to perform their functions, lower government units will try to increase their revenue. Regions with valuable natural resources will tend to maximise benefits from resources in their areas. This tendency is supported by their legal authority to generate local taxes and levies. ${ }^{164}$ Prior to the implementation of decentralisation reform in 2001, the national government amended the Act on Regional Taxes and Levies to accommodate the wide authority of provincial and local government to introduce local taxes and levies. ${ }^{165}$ They were given authority to seek locallygenerated income to support their autonomy. ${ }^{166}$ For regions with valuable forestry resources, exploitation of forest was considered a solution to support local government development funds and the resources provided economic opportunities for local companies. ${ }^{167}$ As a result, exploitation and conversion of forests has occurred widely. ${ }^{168}$ Under these economic conditions and legal changes, the exploitation of the forestry resources is a logical consequence. Without generating adequate funds, they cannot run their authorities to serve the community.

The implementation of the Convention in Indonesia has been problematic. The legal and political issues have mixed and characterised the implementation of the Convention in Indonesia's decentralisation.

\section{Conclusion}

Indonesia's decentralisation provides challenges for national government in performing its commitment under the Convention. These legal and political issues have raised challenges for the implementation of the Convention in Indonesia's decentralisation. This situation suggests that in Indonesia's decentralisation, national government has committed to an international agreement but has faced difficulties in binding its lower government organs to its international commitments.

\section{Bibliography}

Agusman, D. Dumoli. (2008) Status Hukum Perjanjian Internasional Dalam Hukum Nasional Republik Indonesia: Tinjauan dari Perpsektif Praktek Indonesia. Department of Foreign Affairs, Padjajaran University, Bandung.

Ahmad, Ehtisham \& Mansoor, Ali. (2002) "Indonesia: Managing Decentralization IMF"

Resosudarmo, Ida A. P. (2004) "Closer to People and Trees: Will Decentralisation Work for the People and the Forests of Indonesia?". European Journal of Development Research.

Asshidiqie, Jimly. (2006) Pengantar Hukum Tata Negara Jilid, Sekretariat Jendral dan Kepaniteraan Mahkamah Konstitusi, Jakarta.

Asshiddiqie, Jimly. (2010) "Hubungan Antar Lembaga Negara Pasca Perubahan UUD 1945". Constitutional Court.

\footnotetext{
${ }_{164}$ Regional Government Act 200432 (Indonesia), art 21 (e).

165 See the Consideration provision of Regional Tax and Levies Act 200034 (Indonesia).

166 See the Consideration provision of Regional Tax and Levies Act 200034 (Indonesia).

167 Christopher Barr and others, see note 162, p. 79-80.

168 Ibid., p. 2.
} 
Aust, Anthony. Handbook of International Law (Cambridge University Press, New York, 2005).

Aust, Anthony Modern Treaty Law and Practice (2nd ed, Cambridge, UK, 2007).

Barr, Christopher and others Decentralisation of Forest Administration in Indonesia: Implications for Forest Sustainability, Economic Development and Community Livelihoods (CIFOR, Bogor, 2006).

Bertrand, Jacques, "Indonesia's Quasi-Federalist Approach: Accommodation amid Strong Integrationist Tendencies," (2007) 5 (4) International Journal of Constitutional Law, 576.

Birnie, Patricia, Boyle, Alan and Redgwell, Catherine International Law and the Environment (Oxford University Press, New York, 2009).

Bodansky, Daniel The Art and Craft of International Environmental Law (Harvard University Press, Cambridge (Mass) 2010).

Brunnée, Jutta, “COPing with Consent: Law-Making under Multilateral Environmental Agreements" (2002) 15 (1) Leiden Journal of International Law (LJIL).

Butt, Simon, "Regional Autonomy and Legal Disorder: the Proliferation of Local Laws in Indonesia" (2010) Singapore Journal of Legal Studies.

Devas, Nick, "Indonesia: what do we mean by decentralisation?" (1997) 19 Public Administration and Development.

Direktorat Jenderal Hukum dan Perjanjian Internasional, Departemen Luar Negeri Perjanjian Internasional Dalam Teori dan Praktek di Indonesia: Komplilasi Permasalahan (Indonesian Ministry of Foreign Affairs, Jakarta, 2008).

Hadyono, Suparti "Praktek Penerapan Perjanjian Internasional Dalam Putusan Hakim" (2008) Paper Presented in the Focus Group Discussion on the Status of Treaty in Indonesian Legal System, organized by the Ministry of Foreign Affairs and Padjajaran University (Bandung November $29^{\text {th }}, 2008$ ).

Indonesia's Ministry of Environment Rencana Aksi Nasional Dalam Menghadapi Perubahan Iklim (Ministry of Environment, Jakarta, 2007).

Keohane, Robert O. and Raustiala, Kal "Toward A Post-Kyoto Climate Change Architecture: A Political Analysis" (2008) 08-14 UCLA School of Law Law \& Economics Research Paper Series Research Paper.

Kiss, Alexandre and Shelton, Dinah Guide to International Environmental Law (Martinus Nijhooff Publishers, the Netherlands, 2007).

Kusumaatmadja, Muchtar Pengantar Hukum Internasional (vol 1, Ed 9, 1990).

Lindsey, Tim "From Rule of Law to Law of the Rulers-to Reformation?" in Tim Lindsey (Ed) Indonesian Law and society (Federation Press, NSW, Australia, 1999).

Manan, Bagir, "Akibat Hukum di Dalam Negeri Pengesahan Perjanjian Internasional (Tinjauan Hukum Tata Negara" Paper presented in the Focus Group Discussion on the Status of Treaty in Indonesian Legal System, organized by Department of Foreign Affair and Padjajaran University, Bandung November 29th 2008.

McCarthy, John F, "Local Voice in Shifting Modes of Decentralised Resource Control in Central Kalimantan, Indonesia" (2007) 65 Management in Asia-Pacific Working Paper.

Mubyarto, "Otonomi Daerah dan Ekonomi Kerakyatan" in Bonar Simorangkir et al (eds) Otonomi atau Federalisme: Dampaknya terhadap perekonomian (Pustaka Sinar Harapan and Suara Pembaruan, Jakarta, 2000).

Rachbini, Didik J. Politik Ekonomi Baru: Menuju Demokrasi Ekonomi (Grasindo, Jakarta, 2001). 
Shaw, Malcolm N. International Law (5th Ed, Cambridge University Press, New York, 2003).

Situmorang, Albert "Sejarah Pemberontakan di Indonesia: Ketidakpuasan Rasionalisasi" <http://www.indonesia-house.org/archive/060603Sejarah_ pemberontakan.htm> at May 1st 2010.

SMERU, “Indonesia's Decentralisation Policy: initial experiences and emerging problems" (a paper prepared for the third EUROSEAS Conference panel on Decentralisation and Democratization in Southeast Asia, September 2001).

Triggs, Gillian D. International Law: Contemporary Principles and Practices (Butterworths Law, London, 2006).

United Nation Environment Programme (UNEP) Manual on Compliance with and Enforcement of Multilateral Environmental Agreements (UNEP, 2006).

United Nations Development Programme (UNDP) Indonesia, "The Missing Link: the Province and its Roles in Indonesia’s Decentralisation," (May 2009) 5, Policy Paper.

Usui, Norio and Alisjahbana, Armida "Local Development Planning and Budgeting in Decentralized Indonesia: Update" (Paper presented to the international symposium on Indonesia's Decentralisation Policy: problems and policy Directions, September 4-5, 2003).

Warnock, Ailsa Ceri, "The Climate Change Regime: Efficacy, Compliance and Enforcement" (2004) 8 New Zealand Journal of Environmental Law, 99.

\section{Treaties/Legislations/Regulations}

Vienna Convention on Consular Relations (opened for signature 24 April 1963, entered into force 19 March 1967).

United Nations Framework Convention on Climate Change (opened for signature June 20,1992, entered into force 21 March 1994).

ASEAN Charter (adopted in Singapore, November 20, 2007, enter into force December 2008).

Constitution (Indonesia).

Supreme Court Act 197014 (Indonesia).

Validation of the 1963 Vienna Convention Act 19821 (Indonesia)

Environmental Management Act 199723 (Indonesia).

The Regional Government Act 199922 (Indonesia) (revoked).

International Agreement Act 200024 (Indonesia).

Special Autonomy for Papua Province Act 200121 (Indonesia).

Validation on the United Nations Framework Convention on Climate Change (UNFCCC) Act 20046 (Indonesia).

Forming of Laws Act 200410 (Indonesia) (revoked).

Validation of the Kyoto Protocol Act 200417 (Indonesia).

Regional Government Act 200432 (Indonesia).

Validation of Covenant on Economic, Social, and Cultural Rights Act 200511 (Indonesia).

Aceh Government Act 200611 (Indonesia).

Mineral and Coal Mining Act 20094 (Indonesia).

Forming of Law Act 201112 (Indonesia). 
Decision of Constitutional Court No. 33/PUU-IX/2011 on the Examination of Act No. $38 / 2008$ on the Ratification of Charter of the Association of Southeast Asian Nations.

Government Regulation 200175 (Indonesia) on the Second Amendment of the implementation of the Mineral Act No 11/1967.

Government Regulation 200234 (Indonesia) on Forestry Management Regulation.

Government Regulation 20076 (Indonesia) on the Management and the Usage of Forest.

Government Regulation 200738 (Indonesia) on the Sharing of Authority between the National Provincial and Local/City governments.

President Regulation 200846 (Indonesia) on the National Board on Climate Change.

President Regulation 200875 (Indonesia) on the Procedure on Providing Considerations for a Plan of International Agreement, a Plan to Form Laws and Administrative Policy Relating Directly to the Aceh Government.

Supreme Court Regulation 201101 on Judicial Review.

Decision of the Minister of Environment 2005206 on the Clean Development Mechanism. 